SHORT REPORT

\title{
Inhibin $\alpha$-subunit (INHA) gene and locus changes in paediatric adrenocortical tumours from TP53 R337H mutation heterozygote carriers
}

\author{
C A Longui, S H V Lemos-Marini, B Figueiredo, B B Mendonca, M Castro, R Liberatore Jr, \\ C Watanabe, C L P Lancellotti, M N Rocha, M B Melo, O Monte, L E P Calliari, G Guerra-Junior, \\ M T M Baptista, L Sbragia-Neto, A C Latronico, A Moreira, A M D Tardelli, A Nigri, S E Taymans, \\ C A Stratakis
}

J Med Genet 2004;41:354-359. doi: 10.1136/jmg.2004.018978

The R337H TP53 mutation is a low-penetrance molecular defect that predisposes to adrenocortical tumour (ACT) formation in Brazilian and possibly other populations. Additional genetic defects may be responsible for the variable expression of ACTs in these cases. The inhibin $\alpha$ subunit gene (INHA) on 2q33-qter has been implicated in mouse adrenocortical tumourigenesis. We studied 46 pediatric patients with $\mathrm{ACT}$ s from Brazil for INHA genetic alterations; 39 of these patients were heterozygous carriers of the R337H TP53 mutation. We first mapped the INHA gene by radiation hybrid analysis and determined 10 linked microsatellite markers in an area flanked by D2S1371 and D2S206 on 2q33-qter. These markers were then used for loss of heterozygozity $(\mathrm{LOH})$ studies in nine paired germline and tumour DNA samples. Mapping placed the INHA gene in close proximity to D2S2848 (SHGC1 1864) with a log of odds (LOD) score of 5.84. LOH for at least one marker in the region was identified in $8 / 9$ tumours $(89 \%)$. Six patients were heterozygous for three INHA mutations: one in exon 1, $127 C>G$, and two in exon 2, 3998G $>A$ and $4088 G>A$, all leading to amino acid substitutions (P43A, G227R, and A257T, respectively). A257T is located in a conserved INHA region, highly homologous to transforming growth factor- $\beta$; both G227R and A257T change polarity, and, in addition, G227R changes the $\mathrm{pH}$. We conclude that these sequence alterations and the detected $2 q$ allelic changes suggest that INHA may be one of the contributing factors needed for ACT formation in pediatric patient carriers of the R337H TP53 mutation.

A drenocortical tumours (ACTs) are rare, with an estimated incidence in the US of 0.3 per million per year. ${ }^{1}$ In southern Brazil, the incidence is 10-15 times greater, despite no evidence of occupational, endemic, or transmissable diseases that predispose to ACTs. Recently, a germline mutation of the TP53 gene (R337H) was described in 35 of 36 Brazilian children with ACTs. ${ }^{2}$ The same mutation was then identified by Latronico and co-workers in adult, as well as additional paediatric, Brazilian patients with ACTs. ${ }^{3}$ Furthermore, low-penetrance mutations of the TP53 gene were recently identified in other populations. ${ }^{4}$ It appears likely that the tumourigenic effect of the low-penetrance $\mathrm{R} 337 \mathrm{H}$ mutation is related to $\mathrm{pH}$-induced conformational changes in the $\mathrm{p} 53$ protein $^{5} 6$ and/or other factors.

In the case of ACTs in the Brazilian population, it has long been hypothesised that additional germline or somatic mutations of other genes with an established tumourigenic role may act in synergy, or may even be required for adrenocortical tumourigenesis. ${ }^{17}$ The low penetrance of the $\mathrm{R} 337 \mathrm{H}$ mutation could then be explained-only patients who also either carry or acquire additional defects will develop ACTs. Indeed, specific genetic changes may be present in these tumours, such as amplification of the 9q34 chromosomal region, ${ }^{7}$ which has not been reported in any other group of ACTs. ${ }^{8}$

Additional factors that have been implicated in ACT formation and could be present in the tumours of this population include lack of imprinting and overexpression of the insulin-like growth factor II (IGF-II) gene, ${ }^{10} 11$ and possibly over-expression of angiotensin-II, ${ }^{12}$ endothelin-1 and adrenomedullin ${ }^{13}$ and urotensin $\mathrm{II}^{14}$ or under-expression of novH $\mathrm{H}^{15}$ and cAMP early repressor. ${ }^{16}$

Inhibin is a factor that has been associated with ACT formation at least in rodents. ${ }^{17}$ Inhibin is a glycoprotein secreted by the gonads, adrenals, pituitary gland, and pancreas. The complete protein consists of 364 amino acids, with the $\alpha$-subunit corresponding to the C-terminal 134 amino acids. ${ }^{17}$ Characterisation of inhibin c-DNA and genomic sequence led to the recognition of its homology with transforming growth factor- $\beta$ (TGF- $\beta$ ), and its possible role in tissue differentiation and development. ${ }^{18-20}$ The chromosomal localisation of the human inhibin subunit genes was determined by somatic hybrid analysis and reported in $1989 .{ }^{20}$ Alpha, $\beta$-A, and $\beta$-B subunits were mapped to human chromosome 2q33-qter, chromosome 7pl5-pl4, and chromosome 2qcen-q13, respectively. ${ }^{20}$

The human inhibin $\alpha$-subunit gene (INHA) (GenBank accession: NT_005289) is encoded by two exons of 267 and 834 base pairs (bp), respectively. ${ }^{18}{ }^{19}$ In a mouse model, the inhibin $\alpha$-subunit gene $(i n h \alpha)$ was demonstrated to be an important determinant of cortical adrenal tumour development. ${ }^{21}$ Homozygous inh $\alpha^{-/-}$mice developed gonadal tumours at 4-5 weeks of age, and died at 12 weeks. Gonadectomy prior to gonadal tumour formation postponed the wasting syndrome, and allowed the development of ACTs at a later age (21 weeks); death followed at 33-36 weeks.

The results of studies of INHA expression in human ACTs have been less clear as regards its contribution to tumourigenesis. Immunoreactivity for INHA is present in the zona reticularis and in focal collections of cells in the zona fasciculata of the normal adrenal cortex, whereas zona

Abbreviations: ACT, adrenocortical tumour; LOD, log of odds; $\mathrm{LOH}$, loss of heterozygosity; MI, microsatellite length instability; $\mathrm{RH}$, radiation hybrid; TGF- $\beta$, transforming growth factor $-\beta$ 
glomerulosa cells do not demonstrate immunoreactivity for INHA. ${ }^{22-24}$

\section{METHODS}

In this study, we investigated the INHA gene in Brazilian children with ACTs, 39 carriers of the germline R337H TP53 mutation, and seven subjects who served as a control group with ACTs but without this genetic defect. In a small number of tumours from which both germline and tumour DNA was available we examined the INHA 2q locus for allelic losses. To do so accurately, we first mapped the INHA gene by radiation hybrid mapping and identified closely linked polymorphic markers.

Patients for this study were recruited after approval by the Ethical Committee of Santa Casa São Paulo School of Medicine from several centres around Brazil. All patients and/or their legal guardians gave informed consent. A total of 46 children ( 35 females and 11 males) with functional ACTs from 45 unrelated families were studied. Their ages varied between 0.4 and 13.4 years and the mean age was 3.2 years (standard deviation (SD) 2.9; median 2.0 years). The hormonal syndromes associated with these tumours were: virilisation $(n=30)$, Cushing syndrome $(n=1)$, and virilisation in combination with Cushing syndrome $(n=15)$.

Genomic DNA from peripheral blood cells was obtained from all 46 children employing standard DNA extraction methods, as described previously. ${ }^{25}$ Genomic DNA from paraffin-embedded or frozen tumour tissue was extracted from nine samples using the QIA Amp Tissue Kit (QIAGEN, Chatsworth, CA, USA), as described previously. ${ }^{26}$

The DNA analysis for TP53 mutations of these patients has been reported elsewhere. ${ }^{23}$ Out of the 46 patients, 39 were carriers of the R337H TP53 mutation and seven did not have any TP53 coding sequence changes (data not shown).

The 10000 rad Stanford Human Genome Center (SHGC) G3 radiation hybrid (RH) panel from Research Genetics (Huntsville, AL) was used to determine the location of the inhibin gene with respect to polymorphic markers on chromosome 2. PCR was performed twice using a primer pair from an amplicon within the INHA gene (sense-S: 5'-

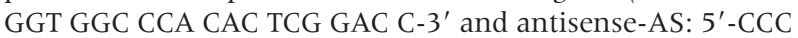
ACC CTT AGA TAC AAG C-3'). The duplicate RH mapping data were submitted to the SHGC-RH mapping server, ${ }^{27}{ }^{28}$ as described previously. ${ }^{25} 29$

\section{RESULTS}

The INHA amplicon most closely mapped to the chromosome 2 marker D2S2848 (also known as SHGC11864), with a logof-odds (LOD) score of 5.84 and an estimated distance of $19.5 \mathrm{cR}_{10,000}$ (approximately $670 \mathrm{~kb}$ for chromosome 2). This sequence, however, was not polymorphic. Close to D2S2848, polymorphic markers (with their distances from the top of chromosome 2 as listed in genome data bases) D2S1371 (113.1 MB), D2S173 (214.5), D2S163 (214.5), D2S126 (214.5), D2S339 (113.1), D2S130 (113.1), D2S408 (113.1), D2S351 (113.1), D2S1363 (113.1), and D2S206 (214.5) $)^{24}$ (which were all linked by RH to the INHA-D2S2848 locus) were chosen for use in the $\mathrm{LOH}$ analysis. The location of the INHA gene is, according to RH analysis, very proximal to D2S2848; the latter's location is shown in figure 1, placed with the other markers in chromosomal order.

Paired (blood-tumour) DNA samples were studied by polymerase chain reaction (PCR) amplification of markers surrounding the INHA gene position (as established by RH mapping), shown in figure 1 . The sequences and genomic order of these primers are available in the genome database on line (http://www-genome.wi.mit.edu). The PCR conditions and methods have been described elsewhere. ${ }^{26}$ Loss of heterozygosity ( $\mathrm{LOH}$ ) was considered to be present when only one allele was evident in DNA extracted from a patient's tumour compared with two alleles in the DNA derived from peripheral blood lymphocytes. Microsatellite length instability (MI) was considered to be present when the amplified tumour DNA contained multiple bands or bands that differed from those seen in DNA from peripheral blood. Specimens that were not successfully amplified were excluded from the analysis. The results were expressed as percentages of the total number of informative loci in both tumour and blood samples.

The LOH analysis was performed in nine patients from whom paired blood and tumour DNA samples were available, eight being carriers of the R337H TP53 mutation and one who was not a carrier. Their clinical characteristics are presented in table 1. The analysis was complicated by considerable microsatellite instability, which is not unusual for telomeric chromosomal locations. ${ }^{26}$ In total, eight of the nine tumours had undergone $\mathrm{LOH}$ for at least one of the chromosome 2 INHA-linked markers (fig 1), although for cases 2, 4, and 9 the informative markers immediately flanking the INHA gene have retained heterozygosity. Patient 1, who did not carry the germline R337H TP53 mutation, is one of the six patients with INHA mutation (see below).

Subsequently, a set of five primer pairs was synthesised to amplify the complete coding region of the inhibin $\alpha$-subunit gene. The first primer pair (INHAI-S: $5^{\prime}$-GTG AGC TAT GGT GCT GCA CCT-3'; INHAl-AS: 5'-CGT TAC CTG TGG CTG GGA AAA GGA-3') was used to amplify exon 1. Exon 2 was amplified with four primer pairs: INHA2-S: 5'-GCA GAT GCC AGC TGT GAG GAC AA-3'; and INHA2-AS: 5' -ATG GCC CAA AGA CAT GGG CA-3'; INHA3-S: 5'-TCA CCG GGA GGA CCC GTG GCT-3'; and INHA3-AS: 5'-GGA GAC CAA GGC CAG GAC ATC A-3'; INHA4-S: 5'-ACG CTC AAC TCC CCT GAT GTC CT-3'; and INHA4-AS: 5'-GAT GTG CAG CCC ACA ACC ACC AT-3'; INHA5-S: 5'-TCA TCT TCC ACT ACT GTC ATG GT- $3^{\prime}$; and INHA5-AS: 5' -ATA CAA GCA CAG TGC TGC GTG AG-3'. These primer pairs generated small-sized fragments of 281, 249, 257, 205 and 244 base pair (bp), respectively. PCR reactions were performed as follows: after an initial denaturation step at $94^{\circ} \mathrm{C}$ for 5 min and 35 cycles $\left(94^{\circ} \mathrm{C}\right.$ for $1 \mathrm{~min}, 60^{\circ} \mathrm{C}$ for $1 \mathrm{~min}$, (for INHA primer-pairs 1, 3, and 4); and $50^{\circ} \mathrm{C}$ for $1 \mathrm{~min}$ (for INHA primer pairs 2 and 5), followed by $72^{\circ} \mathrm{C}$ for $1 \mathrm{~min}$, the samples were submitted to a prolonged extension cycle at $72^{\circ} \mathrm{C}$ for $7 \mathrm{~min}$. PCR products were loaded on a $4-20 \%$ polyacrylamide minigel (Invitrogen-Novex, Carlbad, CA, USA). Electrophoresis was performed in a minicell apparatus (MiniCell X-II, Invitrogen-Novex, Carlbad, CA, USA) at $20 \mathrm{~mA}$, with constant buffer temperature of $18^{\circ} \mathrm{C}$. Running time was about 1.5-2.0 h, depending on the size of each fragment. In order to confirm the molecular size of the bands the samples were loaded in parallel to the D-15 molecular marker (Novex, San Diego, CA, USA). After electrophoresis, the gel was incubated for $30 \mathrm{~min}$ in TBE buffer containing ethidium bromide. Under UV light, the bands were detected and captured by digital photography (DC-120 digital camera, Kodak-Eastman, Rochester, NY, USA). Bidirectional sequencing using the same primers and fluorescent dideoxynucleotides was performed on an Applied Biosystems (Foster City, CA) model ABI 377 automated sequencer.

Abnormal mobility shifts were detected in the germline DNA of 22/46 cases. However, 16 patients had a 3850C $>$ T substitution, which does not change the amino acid alanine at position 177 of the INHA protein (fig 2). This polymorphism abolishes a restriction site in an INHA amplicon. Indeed, the PCR amplicon using the primer pair 3 (INHA3-S/INHA3AS) produces a $257 \mathrm{bp}$ DNA fragment, which after digestion with Sau 96 I (New England Biolabs, Beverly, MA, USA) generates five fragments of $10,20,26,80$, and $121 \mathrm{bp}$. The 


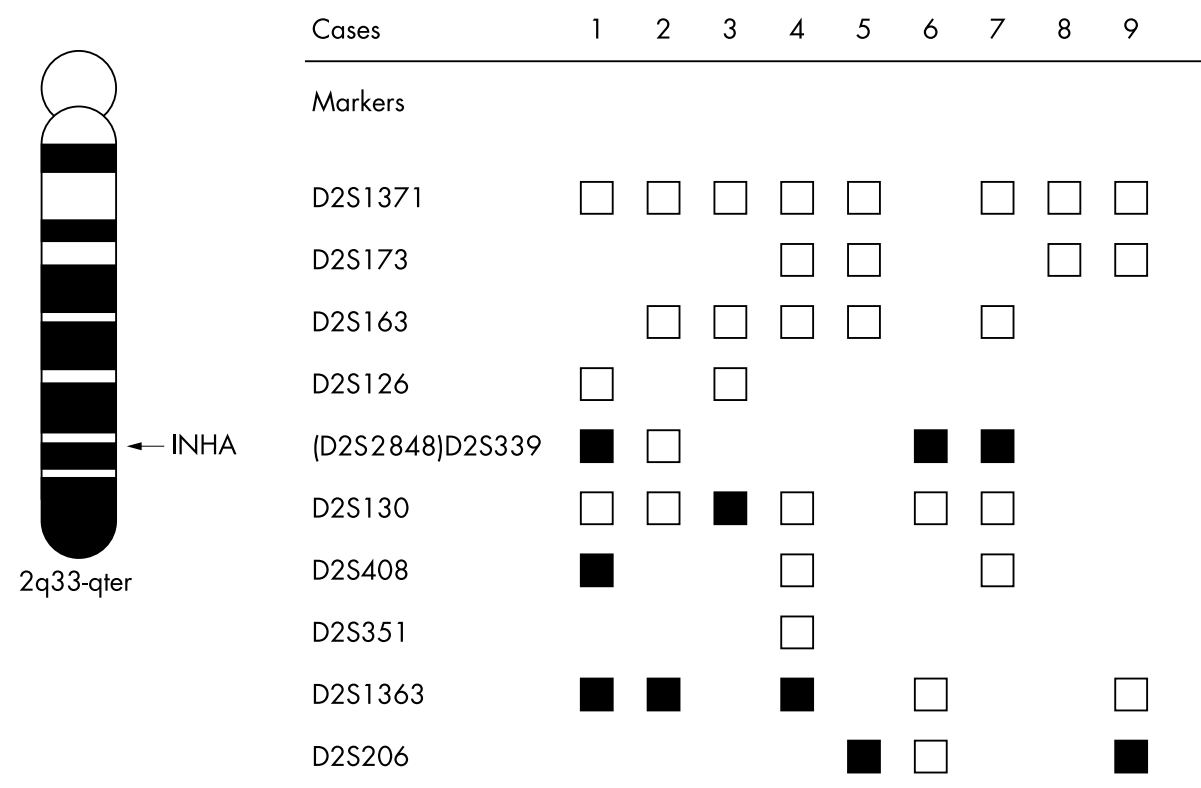

Figure 1 Location of the INHA gene on chromosome 2 (proximal to marker D2S2848); flanking markers were tested for loss of heterozygosity (LOH) in the nine paired blood-tumour DNA samples that were available. $\square$ Indicates a normal result (retention of heterozygosity); $\mathbf{\square}$ indicates LOH; nonchecked squares were uninformative reactions (samples were homozygous in the blood DNA for the respective markers or produced microsatellite instability).

3850C $>\mathrm{T}$ polymorphism abolishes one enzymatic site, resulting in four fragments of $10,26,80$, and $141 \mathrm{bp}$.

The presence of the $3850 \mathrm{C}>\mathrm{T}$ polymorphism was evaluated in our patients and 65 controls (blood donors, 50 males and 15 females, aged $18-45$ years) with digestion by the Sau 96 I endonuclease for $4 \mathrm{~h}$ at $37^{\circ} \mathrm{C}$. After digestion, the samples were loaded on a $3.5 \%$ agarose gel and submitted to electrophoresis at $50 \mathrm{~mA}$ for approximately $3 \mathrm{~h}$ in TBE buffer with ethidium bromide. The bands were detected under UV light and photographed.

Three of our patients were homozygous for this polymorphism and 13 heterozygous. It seems to be an apparently common INHA polymorphism in the Brazilian population, since 19 of 65 normal controls carried the same sequence change, 17 in the heterozygous and two in the homozygous state (table 1). Statistical analyses of the distribution of the polymorphism versus that expected, according to the HardyWeinberg equilibrium, and between the patient and control populations were performed using the $\chi^{2}$ test. There were no deviations from the expected frequencies, nor there were differences between patients and normal subjects $(p>0.05$ for both analyses).
In addition to the polymorphism, three previously undescribed INHA mutations, which were not present in normal controls, were also identified in the heterozygote state in six patients, five with the TP53 $R 337 \mathrm{H}$ mutation and one who did not carry this genetic defect (fig 2). One mutation was found in exon 1 of the INHA gene $(127 \mathrm{C}>\mathrm{G})$ leading to an amino acid substitution (P43A) and two mutations were found in exon 2 (3998G $>$ A and $4088 \mathrm{G}>\mathrm{A}$ ) which also led to amino acid changes (G227A and A257T, respectively). The P43A mutation was found in only one patient, while the G227A and A257T mutations were found in three and two, respectively. All these patients were from different families-each represented a single case of adrenocortical tumour in his/her kindred. In one patient with $\mathrm{LOH}$ in his tumour (patient 1), a mutation was identified. No tumour tissue was available from the other patients to test for INHA LOH.

Of the mutations, A257T is in the conserved INHA region of highest homology with transforming growth factor- $\beta$ (TGF- $\beta$ ); both G227A and A257T may change the polarity of the protein, while G227A may also change its $\mathrm{pH}$. The mutations are close to four conserved cystein residues that

Table 1 Characteristics of the adrenocortical tumours submitted to $\mathrm{LOH}$ analyses

\begin{tabular}{llllllll}
\hline Case & Sex & $\begin{array}{l}\text { Age } \\
\text { (years) }\end{array}$ & Side & $\begin{array}{l}\text { Tumour } \\
\text { function }\end{array}$ & Size $(\mathbf{c m})$ & $\begin{array}{l}\text { LOH } \\
\text { (D2S markers) }\end{array}$ & MI (D2S markers) \\
\hline 1 & $\mathrm{~F}$ & 0.5 & $\mathrm{~L}$ & $\mathrm{Vi}$ & 4.5 & $339 ; 408 ; 1363$ & $1371 ; 126 ; 130$ \\
2 & $\mathrm{~F}$ & 1.8 & $\mathrm{~L}$ & $\mathrm{Vi}$ & $4.0 \times 3.0$ & 1363 & $1371 ; 163 ; 339 ; 130$ \\
3 & $\mathrm{~F}$ & 2.0 & $\mathrm{R}$ & $\mathrm{Vi}+\mathrm{Cu}$ & $4.2 \times 3.5$ & 130 & $1371 ; 163 ; 126$ \\
4 & $\mathrm{~F}$ & 0.8 & $\mathrm{~L}$ & $\mathrm{Vi}$ & 6.0 & 1363 & $1371 ; 173 ; 163 ;$ \\
& & & & & & & $130 ; 408 ; 351$ \\
5 & $\mathrm{M}$ & 2.8 & $\mathrm{~L}$ & $\mathrm{Vi}+\mathrm{Cu}$ & 5.0 & 206 & $1371 ; 173 ; 163$ \\
6 & $\mathrm{M}$ & 2.7 & $\mathrm{R}$ & $\mathrm{Vi}+\mathrm{Cu}$ & $8.0 \times 6.0$ & 339 & $130 ; 1363 ; 206$ \\
7 & $\mathrm{~F}$ & 2.1 & $\mathrm{R}$ & $\mathrm{Vi}$ & $6.3 \times 5.1$ & 339 & $1371 ; 163 ; 130 ; 408$ \\
8 & $\mathrm{~F}$ & 1.5 & $\mathrm{R}$ & $\mathrm{Vi}$ & $4.6 \times 3.0$ & & $1371 ; 173$ \\
9 & $\mathrm{~F}$ & 2.2 & $\mathrm{~L}$ & $\mathrm{Vi}$ & $6.6 \times 5.8$ & 206 & $1371 ; 173$ \\
\hline
\end{tabular}

$\mathrm{Cu}$, Cushing syndrome; F, female; L, left; $L O H$, loss of heterozygosity; $M$, male; $M I$, microsatellite instability; $R$, right; Vi, virilisation. 


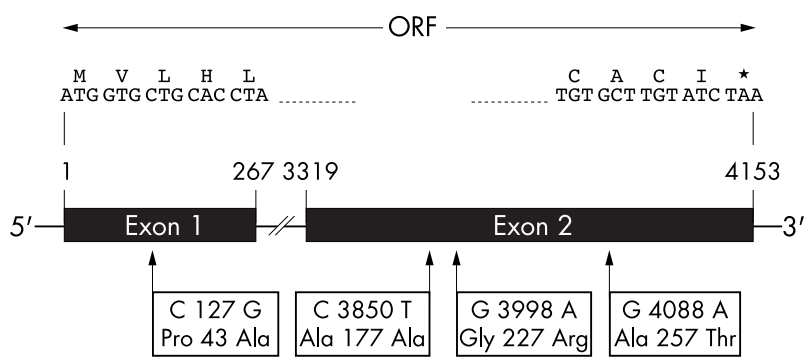

Figure 2 In addition to the polymorphism (3850C $>$ T), three previously undescribed INHA mutations, which were not present in normal controls, were also identified in the heterozygote state in six patients. One mutation was found in exon 1 of the INHA gene $(127 \mathrm{C}>\mathrm{G})$ leading to an amino acid substitution (P43A) and two mutations were found in exon 2 (3998G $>A$ and $4088 G>A$ ) which also led to amino acid changes (G227R and A257T, respectively).Of these, A257T is close to the conserved INHA region of highest homology with transforming growth factor- $\beta$ (TGF- $\beta$ ), G227A and A257T change the polarity of the protein, and $\mathrm{G} 227 \mathrm{~A}$ may also change its $\mathrm{pH}$.

participate in the formation and stability of hydrogen bonds between the subunits (fig 3).

\section{DISCUSSION}

In the present study, we examined paediatric ACTs from $\mathrm{R} 337 \mathrm{H}$ carriers for $\mathrm{LOH}$ of the INHA locus and for germline mutations of the INHA gene. Most cases in which tumour tissue was available had undergone $2 \mathrm{q}$ allelic changes for at least one polymorphic marker in the immediate vicinity of the INHA gene. The LOH data prompted investigation of our paediatric patients for germline mutations of the INHA gene. Consistent with our original hypothesis, three missense mutations of the INHA gene were found in six of our patients and none of these sequence changes were present in the control population. All three mutations are predicted to affect the functional properties of the INHA protein because of corresponding predicted changes in its polarity and/or $\mathrm{pH}$.

A recent review has discussed the body of evidence supporting the role of the INHA gene as a tumour suppressor gene in endocrine oncogenesis. ${ }^{17}$ However, up to now, there have been no reported INHA mutations in human neoplasms, including ACTs. In the present study we hypothesised that perhaps this was because INHA mutations act synergistically or as simple co-factors in the development of neoplasia, as we have suggested elsewhere. ${ }^{1}$ According to this hypothesis, molecular screening of random samples would not have a high likelihood of detecting INHA mutations. Rather, a specific sample, such as that of patients with the lowpenetrance R337H TP53 mutation in the germline heterozygote state, would have to be analysed; in this patient population, other factors had long been postulated to play a role in ACT formation in certain patients and not in others. ${ }^{1-4}$

The intrinsic mechanism by which inhibin may exert its possible tumour suppressive activity is not well understood but appears to be related to its structural and functional homology to TGF- $\beta .^{17}$ Inhibin antagonises activin through a dominant-negative effect involving the binding of inhibin to the activin receptor type II. $^{30}{ }^{31}$ This action is further supported by INHA binding to betaglycan, a type III TGF- $\beta$ receptor, which in turn mediates functional antagonism of activin signalling. ${ }^{32}$ The effects of inhibin on the TGF- $\beta$ signalling pathway could be exerted by binding to betaglycan or inhibin-binding protein. ${ }^{17}$

One possible consequence of the identified INHA mutations would be disruption of the $\alpha / \beta$ dimerisation, allowing for increased formation of $\beta / \beta$ dimers in affected tissues. This apparent imbalance of inhibins $(\alpha / \beta)$ versus $(\beta / \beta)$ activins at the tissue level has been proposed as a potential mechanism for tumour formation and progression. ${ }^{17}$ Additionally, the affinity and stability of the mutant inhibin when bound to its receptors could be altered.

The likely multiple interactions of INHA in tumourigenesis, and its cardinal role in reproduction and gonadal morphogenesis, suggest that if germline INHA mutations did contribute to human neoplastic transformation, they would be mostly missense mutations that would alter some of the functional properties of the molecule but would not completely abolish its activity. This hypothesis was supported by the evidence provided by the preliminary immunohistochemistry studies of INHA and other inhibin and activin subunits, at least in ACTs. ${ }^{22}{ }^{33}$ Unfortunately, no additional tissue was available for immunohistochemistry in the present study.

In our patients and their families there was no increased incidence of other cancers. However, there is evidence suggesting that INHA allelic and sequence changes may be more widespread in endocrine tumourigenesis. First, chromosomal deletions, or even $\mathrm{LOH}$, of genomic regions that harbour genes encoding for inhibin, activin, and their receptors and downstream effectors are frequently observed in tumours of endocrine and non-endocrine tissues, such as adenocarcinomas of the ovary and prostate..$^{174}{ }^{35}$ In ACTs, in particular, $2 \mathrm{q}$ losses have been detected in approximately $42 \%$ of tumours. ${ }^{36}$ Second, "low-penetrance" germline mutations

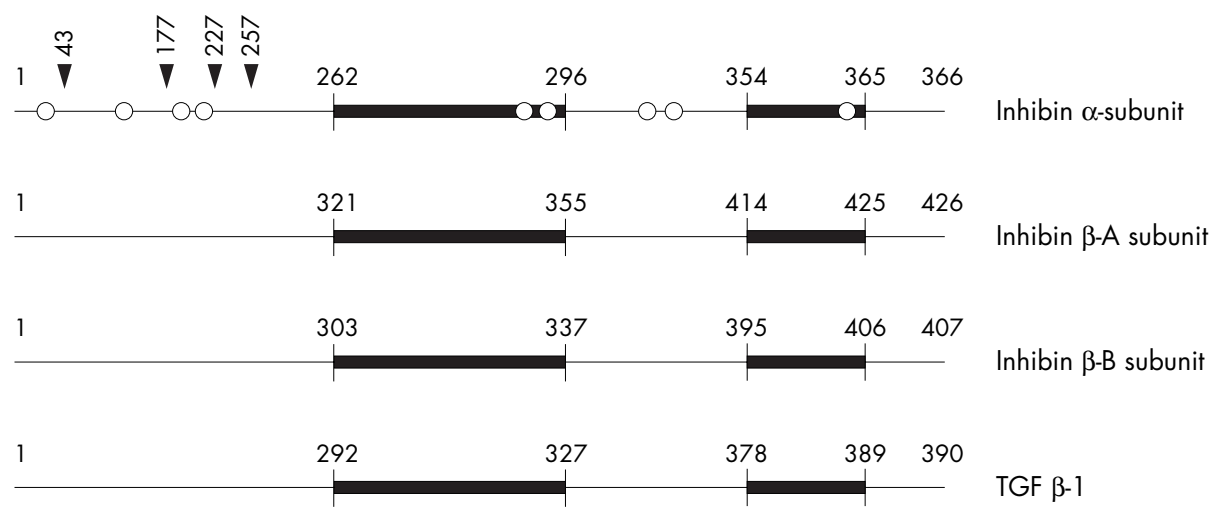

Figure 3 Schematic representation of the location of the identified inhibin $\alpha$-subunit gene (INHA) alterations. The three mutations in codons 43,227 and 257 and the polymorphism in codon 177 are indicated by black arrows. Circles represent the approximate location of cysteine residues and bold lines represent the regions of homology between the various inhibin subunits and TGF- $\beta$ proteins. The 177 polymorphism and the three mutations are close to four conserved cysteine residues that participate in the formation of hydrogen bonds between the subunits. 
of proven or suspected tumour suppressor genes (which have otherwise known lethal or highly deleterious "high penetrance" mutations) have been recently observed in a number of conditions. ${ }^{1}$ It is also possible that simple haploinsufficiency for these mutations predisposes to tumour development, and that $\mathrm{LOH}$ is not necessary.

This is the first study to evaluate INHA molecular genetic involvement in human ACTs. Our findings, albeit preliminary, suggest that this gene may in fact be involved in human adrenocortical tumourigenesis, at least in the context of the R337H TP53 mutation. Our study also provides the genetic location of, and linked markers for, the INHA gene, making future studies of this gene and its locus more accessible to investigators.

\section{ACKNOWLEDGEMENTS}

We thank Dr Fernando Ferreira Costa (Hemocentro, UNICAMP) for support with the sequencing analysis and Dr Lawrence S. Kirschner (now at Ohio State University, Columbus, $\mathrm{OH}$ ) for helpful technical advice on conducting the SSCP experiments. We also thank Dr George Chrousos (PREB, NICHD) for overall facilitation of our studies.

\section{Authors' affiliations}

C A Longui, O Monte, L E P Calliari, Pediatric Endocrinology, Santa Casa de São Paulo, School of Medicine, São Paulo, SP, Brazil

C A Longui, M N Rocha, M B Melo, Laboratory of Molecular Investigation, Santa Casa de São Paulo, School of Medicine, São Paulo, SP, Brazil

C L P Lancellotti, Pathology Department, Santa Casa de São Paulo, School of Medicine, São Paulo, SP, Brazil

S H V Lemos-Marini, M T M Baptista, G Guerra-Junior, L Sbragia-Neto, UNICAMP Pediatric Endocrinology Unit, State University of Campinas, Campinas, SP, Brazil

B Figueiredo, Pediatric Endocrinology, Federal University of Paraná, Curitiba, PR, Brazil

A C Latronico, B B Mendonca, FMUSP-SP Endocrinology Division, University of Sao Paulo, São Paulo, SP, Brazil

M Castro, A Moreira, Endocrinology Unit, University of São Paulo, Ribeirão Preto, Brazil

R Liberatore Jr, Pediatric Endocrinology, School of Medicine, São José do Rio Preto, SP, Brazil

C Watanabe, A M D Tardelli, A Nigri, Pediatric Endocrinology, Catholic University of Sorocaba, Sorocaba, SP, Brazil

S E Taymans, C A Stratakis, Section on Endocrinology and Genetics (SEGEN), Developmental Endocrinology Branch (DEB), National Institute of Child Health and Human Development (NICHD), Bethesda, MD, USA

This work was supported by FAPESP (Foundation for Research Support of São Paulo State), grant process \#: 99/02275-8.

Conflicts of interest: none declared.

Correspondence to: $\operatorname{Dr} C$ A Stratakis, MD, DSc, Chief, Section on Endocrinology and Genetics, DEB, NICHD, NIH, Building 10, Room 10N262, 10 Center MSC1862, Bethesda, 20892-1862, USA stratakc@mail.nih.gov

Revised version received 6 February 2004

Accepted for publication 6 February 2004

\section{REFERENCES}

1 Stratakis CA. Genetics of adrenocortical tumors: gatekeepers, landscapers and conductors in symphony. Trends Endocrinol Metab 2003;14:404-10.

2 Ribeiro RC, Sandrini F, Figueiredo B, Zambetti GP, Michalkiewicz E, Lafferty AR, DeLacerda L, Rabin M, Cadwell C, Sampaio G, Cat I, Stratakis CA, Sandrini R. An inherited p53 mutation that contributes in a tissue-specific manner to pediatric adrenal cortical carcinoma. Proc Natl Acad Sci U S A 2001;98:9330-5

3 Latronico AC, Pinto EM, Domenice S, Fragoso MC, Martin RM, Zerbini MC, Lucon AM, Mendonca BB. An inherited mutation outside the highly conserved DNA-binding domain of the p53 tumor suppressor protein in children and adults with sporadic adrenocortical tumors. J Clin Endocrinol Metab 2001:86:4970-3

4 Varley JM, McGown G, Thorncroft M, James LA, Margison GP, Forster G Evans DG, Harris M, Kelsey AM, Birch JM. Are there low-penetrance TP53 alleles? Evidence from childhood adrenocortical tumors. Am J Hum Genet 1999;65:995-1006.

5 DiGiammarino EL, Lee AS, Cadwell C, Zhang W, Bothner B, Ribeiro RC, Zambetti G, Kriwacki RW. A novel mechanism of tumorigenesis involving pHdependent destabilization of a mutant p53 tetramer. Nat Struct Biol 2002;9:12-6.

6 Hainaut P. Tumor-specific mutations in p53: the acid test. Nat Med 2002:8:21-3.

7 Figueiredo BC, Stratakis CA, Sandrini R, DeLacerda L, Pianovsky MA, Giatzakis C, Young HM, Haddad BR. Comparative genomic hybridization analysis of adrenocortical tumors of childhood. J Clin Endocrinol Metab 1999;84: 1116-21.

8 James LA, Kelsey AM, Birch JM, Varley JM. Highly consistent genetic alterations in childhood adrenocortical tumours detected by comparative genomic hybridization. Br J Cancer 1999;81:300-4.

9 Sidhu S, Marsh DJ, Theodosopoulos G, Philips J, Bambach CP, Campbell P, Magarey CJ, Russell CF, Schulte KM, Roher HD, Delbridge L, Robinson BG. Comparative genomic hybridization analysis of adrenocortical tumors. J Clin Endocrinol Metab 2002;87:3467-74.

10 Logie A, Boulle N, Gaston V, Perin L, Boudou P, Le Bouc Y, Gicquel C. Autocrine role of IGF-II in proliferation of human adrenocortical carcinoma $\mathrm{NCl} \mathrm{H295R} \mathrm{cell} \mathrm{line.} \mathrm{J} \mathrm{Mol} \mathrm{Endocrinol} \mathrm{1999;23:23-32.}$

11 Wilkin F, Gagne N, Paquette J, Oligny LL, Deal C. Pediatric adrenocortical tumors: molecular events leading to insulin-like growth factor II gene overexpression. J Clin Endocrinol Metab 2000;85:2048-56.

12 Cherradi N, Bideau M, Arnaudeau S, Demaurex N, James RW, Azhar S, Capponi AM. Angiotensin II promotes selective uptake of high density lipoprotein cholesterol esters in bovine adrenal glomerulosa and human adrenocortical carcinoma cells through induction of scavenger receptor class B type I. Endocrinology 2001;142:4540-9.

13 Takahashi K, Yoshinoya A, Murakami O, Totsune K, Shibahara S. Production and secretion of two vasoactive peptides, adrenomedullin and endothelin-1, by cultured human adrenocortical carcinoma cells. Peptides 2000;21:251-6.

14 Takahashi K, Totsune K, Murakami O, Shibahara S. Expression of urotensin II and urotensin II receptor mRNAs in various human tumor cell lines and secretion of urotensin II-like immunoreactivity by SW-13 adrenocortical carcinoma cells. Peptides 2001;22:1175-9.

15 Martinerie C, Gicquel C, Louvel A, Laurent M, Schofield PN, Le Bouc Y. Altered expression of novH is associated with human adrenocortical tumorigenesis. J Clin Endocrinol Metab 2001;86:3929-40.

16 Peri A, Luciani P, Conforti B, Baglioni-Peri S, Cioppi F, Crescioli C, Ferruzzi P, Gelmini S, Arnaldi G, Nesi G, Serio M, Mantero F, Mannelli M. Variable expression of the transcription factors $C A M P$ response element-binding protein and inducible CAMP early repressor in the normal adrenal cortex and in adrenocortical adenomas and carcinomas. J Clin Endocrinol Metab 2001;86:5443-9

17 Risbridger GP, Schmitt JF, Robertson DM. Activins and inhibins in endocrine and other tumors. Endocr Rev $2001 ; 22: 836-58$

18 Mason AJ, Hayflick JS, Ling N, Esch F, Ueno N, Ying SY, Guillemin R, Niall H, Seeburg PH. Complementary DNA sequences of ovarian follicular fluid inhibin show precursor structure and homology with transforming growth factor- $\beta$. Nature (London) 1985;318:659-63.

19 Mason AJ, Niall HD, Seeburg PH. Structure of two human ovarian inhibins. Biochem Biophys Res Commun 1986;135:957-64.

20 Barton DE, Yang-Feng TL, Mason AJ, Seeburg PH, Francke U. Mapping of genes for inhibin subunits $\alpha, \beta A$, and $\beta B$ on human and mouse chromosomes and studies of jsd mice. Genomics 1989;5:91-9.

21 Matzuk MM, Finegold MJ, Mather JP, Krummen L, Lu H, Bradley A. Development of cancer cachexia-like syndrome and adrenal tumors in inhibindeficient mice. Proc Natl Acad Sci U S A 1994:91:8817-21.

22 McCluggage WG, Burton J, Maxwell P, Sloan JM. Immunohistochemical staining of normal, hyperplastic, and neoplastic adrenal cortex with a monoclonal antibody against alpha inhibin. J Clin Pathol 1998:51:114-6.

23 Vanttinen T, Kuulasmaa T, Liu J, Voutilainen R. Expression of activin/inhibin receptor and binding protein genes and regulation of activin/inhibin peptide secretion in human adrenocortical cells. J Clin Endocrinol Metab 2002;87:4257-63.

24 Vanttinen T, Liu J, Kuulasmaa T, Kivinen P, Voutilainen R. Expression of activin/inhibin signaling components in the human adrenal gland and the effects of activins and inhibins on adrenocortical steroidogenesis and apoptosis. J Endocrinol 2003;178:479-89.

25 Stratakis CA, Taymans SE, Daruwala R, Song J, Levine M. Mapping of the human genes (SLC23A2 and SLC23A1) coding for vitamin C transporters 1 and 2 (SVCT1 and SVCT2) to $5 q 23$ and 20p12, respectively. J Med Genet 2000;37:E2O(1-3).

26 Stratakis CA Jenkins RB, Pras E, Mitsiadis CS, Raff SB, Stalboerger PG Tsigos C, Carney JA, Chrousos GP. Cyłogenetic and microsatellite alterations in tumors from patients with the syndrome of myxomas, spotty skin pigmentation, and endocrine overactivity (Carney complex). J Clin Endocrinol Metab 1996:81:3607-14

27 Cox DR, Burmeister M, Price ER, Kim S, Meyers RM. Radiation hybrid mapping: a somatic cell technique for constructing high resolution maps of mammalian chromosomes. Science 1990;250:245-50.

28 Spur NK, Bashir R, Bushby K, Cox A, Cox S, Hilde Brandt F, Hill N, Kao FT, Krols L, Marzella R, Miller N, Nothwang HG, Rocchi M, Sarfarazi M, Stratakis CA, Wallgren-Petterson C, Naylor S. Report and abstracts of the Fourth International Workshop on Human Chromosome 2 Mapping 1996. Cytogenet Cell Genet 1996;73:255-73.

29 Taymans SE, Kirschner LS, Giatzakis C, Stratakis CA. Radiation hybrid mapping of chromosomal region 2p15-pl6: integration of expressed and 
polymorphic sequences maps at the Carney complex (CNC) and Doyne honeycomb retinal dystrophy (DHRD) loci. Genomics 1999;56:344-9.

30 Xu J, McKeehan K, Matsuzaki K, McKeehan WL. Inhibin antagonizes inhibition of liver cell growth by activin by a dominant-negative mechanism. J Biol Chem 1995:270:6308-13.

31 Martens JW, de Winter JP, Timmerman MA, Mcluskey A, van Schaik RH, Themmen AP, de Jong $\mathrm{FH}$. Inhibin interferes with activin signalling at the level of the activin receptor complex in Chinese hamster ovary cell. Endocrinology 1997; 138:2928-36.

32 Lewis KA, Gray PC, Blount AL, MacConell LA, Wiater E, Bilezikjian LM, Vale W. Betaglycan binds inhibin and can mediate functional antagonism of activin signalling. Nature 2000;404:411-4.
33 Stratakis CA Chrousos GP. Adrenal cancer. Endocrinol Metab Clin North Am 2000;29:15-25

34 Watson RH, Roy WJ Jr, Davis M, Hitchcock A, Campbell IG. Loss of heterozygosity at the alpha-inhibin locus on chromosome $2 q$ is not a feature of human granulosa cell tumors. Gynecol Oncol 1997; 65:387-90.

35 Dowling CR, Risbridger GP. The role of inhibins and activins in prostate cancer pathogenesis. Endocr Relat Cancer 2000;7:243-56.

36 Zhao J, Speel EJ, Muletta-Feurer S, Rutimann K, Saremaslani P, Roth J, Heitz PU, Komminoth P. Analysis of genomic alterations in sporadic adrenocortical lesions. Gain of chromosome 17 is an early event in adrenocortical tumorigenesis. Am J Pathol 1999;155:1039-45. 